\title{
Analysis of chickpea yield gap and water-limited potential yield in Iran
}

\author{
Afshin Soltani ${ }^{\mathrm{a}, *}$, Amir Hajjarpour ${ }^{\mathrm{a}}$, Vincent Vadez ${ }^{\mathrm{b}}$ \\ a Agronomy Group, Gorgan University of Agricultural Sciences and Natural Resources, Gorgan 49138-15739, Iran \\ ${ }^{\mathrm{b}}$ International Crops Research Institute for the Semi-Arid Tropics (ICRISAT), Patancheru 502324 Greater Hyderabad, Andhra Pradesh, India
}

\section{A R T I C L E I N F O}

\section{Article history:}

Received 1 June 2015

Received in revised form 18 October 2015

Accepted 19 October 2015

\section{Keyword:}

Yield gap

Potential yield

Food security

Chickpea

Simulation

\begin{abstract}
A B S T R A C T
Iran is one of the major chickpea (Cicer arietinum L.) producing countries of the world. Average chickpea yield in Iran is about $500 \mathrm{~kg} \mathrm{ha}^{-1}$ while the world average is $900 \mathrm{~kg} \mathrm{ha}^{-1}$. The objective of this study was to investigate chickpea water limited potential yield $\left(Y_{\mathrm{w}}\right)$ and yield gap in Iran. The analysis was based on data from five representing chickpea producing locations of Iran. Estimated country $Y_{\mathrm{w}}$ and yield gap were 991 and $463 \mathrm{~kg} \mathrm{ha}^{-1}$, respectively, indicating that farmers have reached 53\% (range: 38-64\%) of $Y_{\mathrm{w}}$. If farmers could reach $80 \%$ of $Y_{\mathrm{w}}$ of their locations, by improving agronomy practice, country average yield would increase by $50 \%$, from 528 to $793 \mathrm{~kg} \mathrm{ha}^{-1}$. A key finding of the study was that chickpea yield in Iran is largely limited by inefficient use of environmental resources and not the genetics of the current cultivars. Much higher yield increase is obtainable via an agronomic option than a genetic improvement option: using shorter duration cultivars increased $Y_{\mathrm{w}}$ to $1237 \mathrm{~kg} \mathrm{ha}^{-1}$ ( $25 \%$ increase), but applying a single irrigation of $60 \mathrm{~mm}$ at first-pod alone or in combination with shorter duration cultivars increased $Y_{\mathrm{w}}$ to $1804 \mathrm{~kg} \mathrm{ha}^{-1}$ (85\% increase) and to $1997 \mathrm{~kg} \mathrm{ha}^{-1}$ (104\% increase), respectively. Thus, tripling chickpea production would be feasible using a single irrigation with or without shorter duration cultivars (from 528 to 1443 or $1598 \mathrm{~kg} \mathrm{ha}^{-1}$ ). The availability of water for the single irrigation is discussed.
\end{abstract}

(C) 2015 Elsevier B.V. All rights reserved.

\section{Introduction}

The global population is predicted to increase to 9-10 billion by 2050 (O'Neill et al., 2010), which will require $70-110 \%$ rise in food production (Tilman et al., 2011; FAO, 2009; Ray et al., 2013). Ensuring global food security and protecting the environment at the same time is perhaps the single greatest scientific challenge facing humankind (Cassman, 2012). A number of options have been proposed to help address the food security challenge (Foley et al., 2011; Smith, 2013), among them one promising option is bridging the yield gap (van Ittersum et al., 2013), especially in developing countries (Cassman, 2012). The yield gap is the difference (gap) between yield currently achieved on farms and those that can be achieved by using the best agronomy practice (van Ittersum et al., 2013). Increasing food production via closing yield gap has less environmental consequences than expanding food production area (van Wart et al., 2013; Soltani et al., 2013, 2014). On the other hand, increasing cultivated areas is difficult or virtually impossible in population-dense area like most of the middle- and far- East, where suitable land for agricultural production is limited

\footnotetext{
* Corresponding author. Fax.: + 981732427060 .

E-mail address: afsoltani@yahoo.com (A. Soltani).
}

and in competition with non-agricultural uses (Bruinsma, 2009). Increased production per unit area through genetic improvement may be a suitable solution to increase food production and improve food security, but achievement in a short period of time is also very difficult (Hall and Richards, 2013; Meng et al., 2013).

Yield gap analysis has been under attention since old time (Alberda, 1962), but it has attracted much attention recently due to global food security concern (Lobell et al., 2009; Foley et al., 2011; van Ittersum et al., 2013; Wang et al., 2015). van Ittersum et al. (2013) in a review of yield gap analysis, emphasizing the need for sustainable intensification, stated that identifying regions with greatest potential to increase food supply is critical. Quantifying the yield gap is also essential to inform policies and prioritize research to achieve food security without environmental degradation (van Wart et al., 2013). Therefore, worldwide studies are required to fulfill this need.

Most of the research on yield gap analysis has been done on cereals, especially wheat, maize and rice which provide a large part of the human food (e.g. Hochman et al., 2013; Meng et al., 2013; Lu and Fan, 2013; Schulthess et al., 2013; Tanaka et al., 2013). Yield gap studies on pulse crops are rare, except for the work of Bhatia et al. (2006) that analyzed yield gap of chickpea (Cicer arietinum L.) and some other legume crops in India. Monzon et al. (2013) also conducted yield gap analysis for soybean in Argentina. 
Pulse crops, including chickpea, increase sustainability of agricultural production systems (Soltani et al., 2006), thus, evaluation of their production situation appears essential due to their importance in feeding and their role in cropping system patterns and sustainability. Yield gap of chickpea has not been investigated in Iran.

According to FAO, Iran is one of the major chickpea producing countries of the world (FAO, 2012). In Iran, chickpea is the most important pulse crop with respect to production and area under cultivation (Anonymous, 2013). This crop is cultivated in about 500,000 ha, of which over 95 percent are grown under rainfed conditions (Sabaghpour et al., 2006). Average chickpea yield in Iran is about 400 to $600 \mathrm{~kg} \mathrm{ha}^{-1}$, which is well below the world average of $900 \mathrm{~kg} \mathrm{ha}^{-1}$ (Anonymous, 2013; FAO, 2012). It seems the importance of the crop is increasing in Iran and other developing countries in the West Asia and North Africa (WANA) region with increase in population and limited access to sources of animal protein. WANA region is characterized by high population growth, low and erratic rainfall, limited arable land, and severely limited water resources. Some other countries in the region with low chickpea yield are Pakistan, Syria, Morocco, Algeria, Iraq and Eritrea (Akibode and Maredia, 2011). In addition, countries like India have become net importers of pulse grains including chickpea, which opens a potential market, and therefore much emphasis has been given on that crop now (Ali and Gupta 2012).

The main objective of this study was, therefore, to investigate chickpea water-limited potential yield and yield gap in major chickpea producing areas of Iran. Also, considering the study of Soltani et al. (2001) and of Vadez et al. (2012) that supplementary irrigation would greatly increases chickpea yield and Soltani and Sinclair (2012b) that using early maturing chickpea cultivars would increase crop yield, another objective of this research was to evaluate water- limited potential yield and gap under conditions of using one single supplementary irrigation or short-duration cultivars.

\section{Methods}

\subsection{Locations}

The assessment was conducted for five chickpea producing locations of Iran including Kermanshah, Maragheh, Bojnord, Gonbad, and Zanjan (Table 1). Kermanshah and Maragheh were selected from main chickpea growing area of Iran located in the north west of the country that is responsible for nearly $50 \%$ of total production (Sadri and Banai, 1996). Two main stations of Dryland Agricultural Research Institute (DARI) of Iran are located in Maragheh (main station for cold areas) and Kermanshah (main station for temperate areas). Other locations were selected from other chickpea growing areas spread over the country.

\subsection{Yield data}

For each location, actual yield data were obtained from local agricultural departments for 12 recent years, which is a recommended timeframe for yield gap analysis under water-limited conditions (van Ittersum et al., 2013; Kassie et al., 2014). As stated by van Ittersum et al. (2013) the number of years used for estimating actual yield must be a compromise between variability in yields and the necessity to avoid confounding effects of temporal yield trends due to technological or climate change. Shorter timeframe may be insufficient to capture year-to-year variability in actual yield and longer timeframe may include effects on yield from technological changes or climate change.

Potential yield under radiation-limited conditions $\left(Y_{\mathrm{p}}\right)$ and water-limited conditions $\left(Y_{\mathrm{w}}\right)$ was estimated using a chickpea model, SSM-Chickpea (Soltani and Sinclair, 2011). $Y_{\mathrm{p}}$ is defined as the yield of a crop cultivar when grown without water and nutrient limitation and biotic stress being effectively controlled. This is typically the experimental farm yield. $Y_{\mathrm{w}}$ is defined as the maximum yield that can be obtained from a crop cultivar in a specific rainfed location without any nutritional and biotic limitations (van Ittersum et al., 2013). This is also the experimental station yield where the crop does not receive any supplementary irrigation. As the grain water content of chickpea is about $12 \%$ at harvest time, simulated grain yield presented in this paper were also adjusted for this percentage of moisture content. Crop models are considered the most reliable way to estimate $Y_{\mathrm{p}}$ and $Y_{\mathrm{w}}$ as they account for variation in weather, soil, crop and management and their interactions (van Ittersum et al., 2013).

\subsection{The crop model}

The SSM-Chickpea model simulates phenological development, leaf development and senescence, dry matter production and partitioning, plant nitrogen balance, yield formation and soil water balance. Responses of crop processes to environmental factors of solar radiation, photoperiod, temperature, nitrogen and water availability, and genotype differences were included in the model. The model uses a daily time step and readily available weather and soil information. The model has been extensively tested using independent data from a wide range of growth and environmental conditions across Iran (Soltani et al., 2006; 2011; Amiri Deh Ahmadi et al., 2014) and some other countries (e.g. Vadez et al., 2013). In most cases, simulated grain yield were similar to observed yield with a root mean square error of less than $15 \%$ of average measured yield (Appendix A). For more detailed description of the model refer to Soltani and Sinclair $(2011,2012 a)$. The model can also be downloaded from "https://sites.google.com/site/CropModeling”.

\subsection{Simulations}

Weather data of the locations, including precipitation and maximum and minimum temperature, were available from Iran Meteorological Organization. Solar radiation was estimated using sunshine hours and extraterrestrial radiation (Soltani and Hoogenboom, 2003a,b; Soltani and Sinclair, 2012a).

According to the gathered local data, the following typical farmers' sowing dates were chosen for crop simulations: 1 April for Maragheh, 5 April for Zanjan, 20 April for Bojnord, 20 October for Kermanshah and 15 November for Gonbad. Simulations were performed for local cultivars which were Jam in Maragheh, Zanjan and Bojnord, Hashem in Gonbad and Beauvanij in Kermanshah.

The model was run for 12 years at each location (Table 1 ) to obtain $Y_{\mathrm{p}}$ and $Y_{\mathrm{w}}$. Plant density was 33 plants $\mathrm{m}^{-2}$. A soil with a volumetric water content of $0.13 \mathrm{~cm} \mathrm{~cm}^{-1}$, albedo of 0.12 , curve number of 79 and depth of $100 \mathrm{~cm}$ was used in the simulation at all the selected sites, except for Zanjan where a soil depth of $90 \mathrm{~cm}$ was chosen. One advantage of the model is that it uses volumetric extractable water content which is fairly constant at $0.13 \mathrm{~cm} \mathrm{~cm}^{-1}$ unless soil sand percentage is higher than $80 \%$ (Ritchie et al., 1999). The selected soil depth is based on a report of Dewan and Famouri (1964) which is an output of a joint project between Iran's Ministry of Agriculture and FAO. According to the report of the project, majority of dryland soils have $50-150 \mathrm{~cm}$ depth. The selection of soil depth of $100 \mathrm{~cm}$ in the study is also a reflection of chickpea effective water extraction depth which is typically $100 \mathrm{~cm}$ based on reports from locations in Iran and other parts of WANA region (e.g. Silim and Saxena, 1993; Soltani and Sinclair, 2011); with a soil depth of $>100 \mathrm{~cm}$, effective extraction depth remains $100 \mathrm{~cm}$. Soil nitrogen content that the crop may uptake before activation of biological nitrogen fixation was $3 \mathrm{~g} \mathrm{~N} \mathrm{~m}^{-2}$. Soil water 
Table 1

Geographical and climatic characteristics of the selected locations. Mean temperatures and precipitations are for chickpea growing seasons at each location.

\begin{tabular}{|c|c|c|c|c|c|c|}
\hline Station & Latitude (degrees-minutes) & Longitude (degrees-minutes) & Elevation (ma.s.l.) & Base period (Year) & Mean temp $\left({ }^{\circ} \mathrm{C}\right)$ & Percipitation (mm) \\
\hline Gonbad & $37^{\circ} 15^{\prime} \mathrm{N}$ & $55^{\circ} 01^{\prime} \mathrm{E}$ & 37.2 & 2000-2011 & 14 & 353 \\
\hline Kermanshah & $34^{\circ} 21^{\prime} \mathrm{N}$ & $47^{\circ} 09^{\prime} \mathrm{E}$ & 1318.9 & $2000-2011$ & 12 & 362 \\
\hline Maragheh & $37^{\circ} 24^{\prime} \mathrm{N}$ & $46^{\circ} 16^{\prime} \mathrm{E}$ & 1477.7 & 2000-2011 & 16.5 & 158 \\
\hline Bojnord & $37^{\circ} 28^{\prime} \mathrm{N}$ & $57^{\circ} 19^{\prime} \mathrm{E}$ & 1091 & $2000-2011$ & 21 & 92 \\
\hline Zanjan & $36^{\circ} 41^{\prime} \mathrm{N}$ & $48^{\circ} 29^{\prime} \mathrm{E}$ & 1663 & $2000-2011$ & 18 & 120 \\
\hline
\end{tabular}

content at the sowing time was calculated using a simple soil water balance model (Soltani and Sinclair, 2012a). The model accounted for water addition from rainfall and water removal due to soil evaporation, run- off and deep drainage.

\subsection{Yield gap analysis}

Yield gap $\left(Y_{g}\right)$ was estimated as the difference between waterlimited potential yield $\left(Y_{\mathrm{w}}\right)$ and average farmers yield (actual yield; $\left.Y_{a}\right)$ :

$Y_{\mathrm{g}}=Y_{\mathrm{w}}-Y_{\mathrm{a}}$

Relative yield was obtained as $Y_{\mathrm{a}} / Y_{\mathrm{w}} \times 100$ which indicate how farmers' yields are far or close to $Y_{\mathrm{w}}$. Relative yield gap was calculated as $Y_{\mathrm{g}} / Y_{\mathrm{w}} \times 100$. Yield increase if farmers can reach $80 \%$ of water-limited potential yield of their locations was also calculated. The limit of $80 \%$ is based on Lobell et al. (2009) and van Ittersum et al. (2013). The reason is that the perfection of soil and crop management by all farmers is neither possible nor cost-effective.

Soltani et al. (2001) indicated that supplemental irrigation could greatly increase chickpea yield under semi-arid conditions of Maragheh. Vadez et al., (2012) also showed across 14 locations of the chickpea growing area in India that $30 \mathrm{~mm}$ of irrigation applied at the beginning of seed growth would increase yield by $30 \%$ on average. These simulations were recently confirmed from experimental observations (Vadez, personal communication). Assuming that extra water will be available for chickpea by increasing irrigation efficiency at the locations or saving from other uses, water-limited yield potential with supplemental irrigation $\left(Y_{\mathrm{i}}\right)$ was also simulated. In the simulation, it was assumed that chickpea crop can be irrigated at first-pod stage with a single irrigation of $60 \mathrm{~mm}$. Irrigation efficiency of $100 \%$ was assumed in the simulation. [Irrigation efficiency is the ratio of the amount of water utilized by the crop to the amount of water supplied through irrigation.] So, for an irrigation efficiency of 50\%, $120 \mathrm{~mm}$ irrigation water will be needed.

Soltani and Sinclair (2012b) showed that using early maturing cultivars resulted in $13-14 \%$ yield increase under rainfed conditions of Gonbad and Tabriz (a location near to Maragheh). They simulated early cultivars by $20 \%$ reduction of biological day requirement from emergence to flowering. It has already been reported that there is genetic variation in chickpea for days to flowering and there are many cultivars with shorter duration introduced by ICRISAT and ICARDA (Gaur et al., 2008; Vadez et al., 2013). Thus, this option seems feasible for increased production. In the current study, potential yield under water-limited condition of these shorter duration cultivars $\left(Y_{\mathrm{e}}\right)$ was also simulated by reducing biological day requirement from emergence to flowering by $20 \%$.

And, finally, water-limited potential yield of the shorter duration cultivars under a single irrigation $(60 \mathrm{~mm})$ at first-pod $\left(Y_{\mathrm{ie}}\right)$ was simulated and used in the analysis. It should be noted that we also tested single irrigation at first-pod plus using longer duration cultivars. However, the results showed that even with a single irrigation, shorter duration cultivars performed better (data not shown).

Country averages of actual and water-limited potential yields and yield gap were calculated as weighted average from selected sites. Chickpea is grown in 24 out of 30 provinces of the country, but only five provinces have a share of more than $5 \%$ in the country production and six provinces have a share of more than $2 \%$ in the country production (data not shown). Average chickpea producing area of Iran is 485,515 ha $(2008-11)$ of which 427,688 ha (88\%) is located in the five provinces. The climate of the chickpea producing areas in the five provinces was examined by evaluation of climatic statistics of 72 weather stations. It was found that the stations have very cold (10\%), cold (74\%), temperate (15\%) and warm (2\%) temperature regimes. With respect to moisture, they have semi-arid ( $83 \%$ ) or sub- humid (17\%) regimes. The examination further indicated that $7 \%$ of the locations are similar to Bojnord, $7 \%$ similar to Zanjan, 74\% similar to Maragheh, 6\% similar to Kermanshah and $6 \%$ similar to Gonbad. Thus, weights of 0.07 for Bojnord and Zanjan, 0.74 for Maragheh and 0.06 for Kermanshah and Gonbad were used in calculation of the weighted means. The weighted means are representative of country means.

\section{Results}

\subsection{The environments and resultant $Y_{p}$ and $Y_{w}$}

Mean monthly maximum temperature, minimum temperature, and monthly total precipitation of the selected sites are presented in Fig. 1. The climate is temperate-semiarid in Gonbad, coldsub-humid in Kermanshah, cold-semiarid in Maragheh, cold-arid in Bojnord and Zanjan based on Emberger climate classification method. At all the locations, rainfall occurs in autumn, winter and early spring when temperatures are low. From March/April onwards the locations experience increased radiation and temperature and a rapid fall in rainfall, and hence an ever-increasing evaporative demand. The reduction of rainfall is less evident in Gonbad compared to other locations. Maragheh, Bojnord and Zanjan have cold winters, so chickpea is sown in spring. However, it is sown in autumn in Kermanshah and Gonbad which have mild winters. In Gonbad and Kermanshah, the growing season of chickpea starts from October (Month 11) and continues until June (Gonbad) or July (Kermanshah). In Maragheh, Bojnord and Zanjan, the growing season starts from late March and April and continues until July and early August (Fig. 1).

To provide an image of the magnitude of the terminal drought, $Y_{\mathrm{p}}$ and $Y_{\mathrm{w}}$ of the locations were calculated and compared (Table 2; Fig. 2). Mean $Y_{p}$ across location was $3863 \mathrm{~kg} \mathrm{ha}^{-1} \quad(\mathrm{CV}=6 \%$; $\mathrm{CV}=$ standard deviation/mean), but it ranged from $3188 \mathrm{~kg} \mathrm{ha}^{-1}$ in Zanjan to $4353 \mathrm{~kg} \mathrm{ha}^{-1}$ in Kermanshah. $\mathrm{Y}_{\mathrm{w}}$ mean was $947 \mathrm{~kg} \mathrm{ha}^{-1}$ $(\mathrm{CV}=41 \%)$ and varied from $638 \mathrm{~kg} \mathrm{ha}^{-1}$ in Bojnord to $1565 \mathrm{~kg} \mathrm{ha}^{-1}$ in Gonbad. Country mean of $Y_{\mathrm{p}}$ and $Y_{\mathrm{w}}$ were 3973 and $991 \mathrm{~kg} \mathrm{ha}^{-1}$, respectively. $Y_{\mathrm{w}}$ values were 16 to $39 \%$ (average of $25 \%$ ) of $Y_{\mathrm{p}}$ values with a CV of seven times greater, indicating terminal drought hugely changed chickpea yield and yield variability in Iran.

\subsection{Actual yields $\left(\mathrm{Y}_{a}\right)$}

$Y_{\mathrm{a}}$ showed a wide range of variation from a minimum of $58 \mathrm{~kg} \mathrm{ha}^{-1}$ in Zanjan to a maximum of $1068 \mathrm{~kg} \mathrm{ha}^{-1}$ in Gonbad with a CV of $22 \%$ (Gonbad) to $34 \%$ (Maragheh) (Table 2; Fig. 2). The ranges were different depending on location and year (Fig. 2). Gonbad 

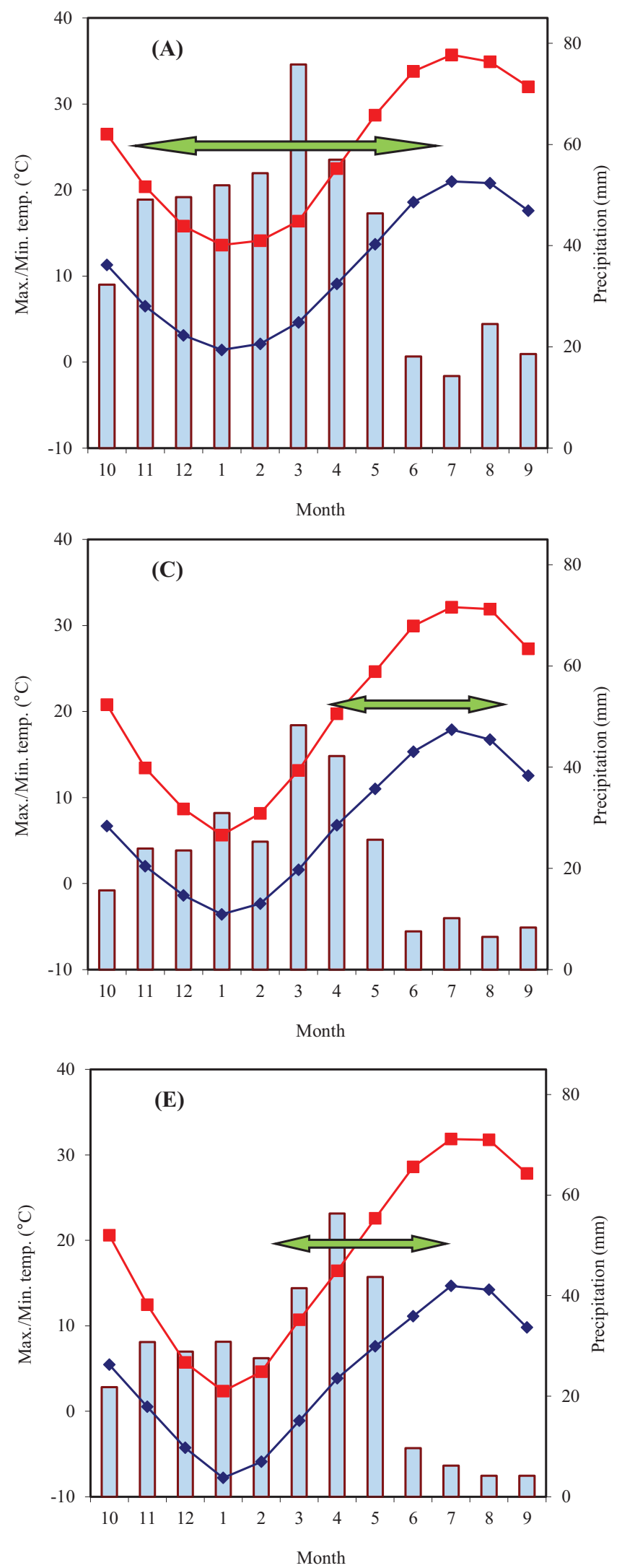
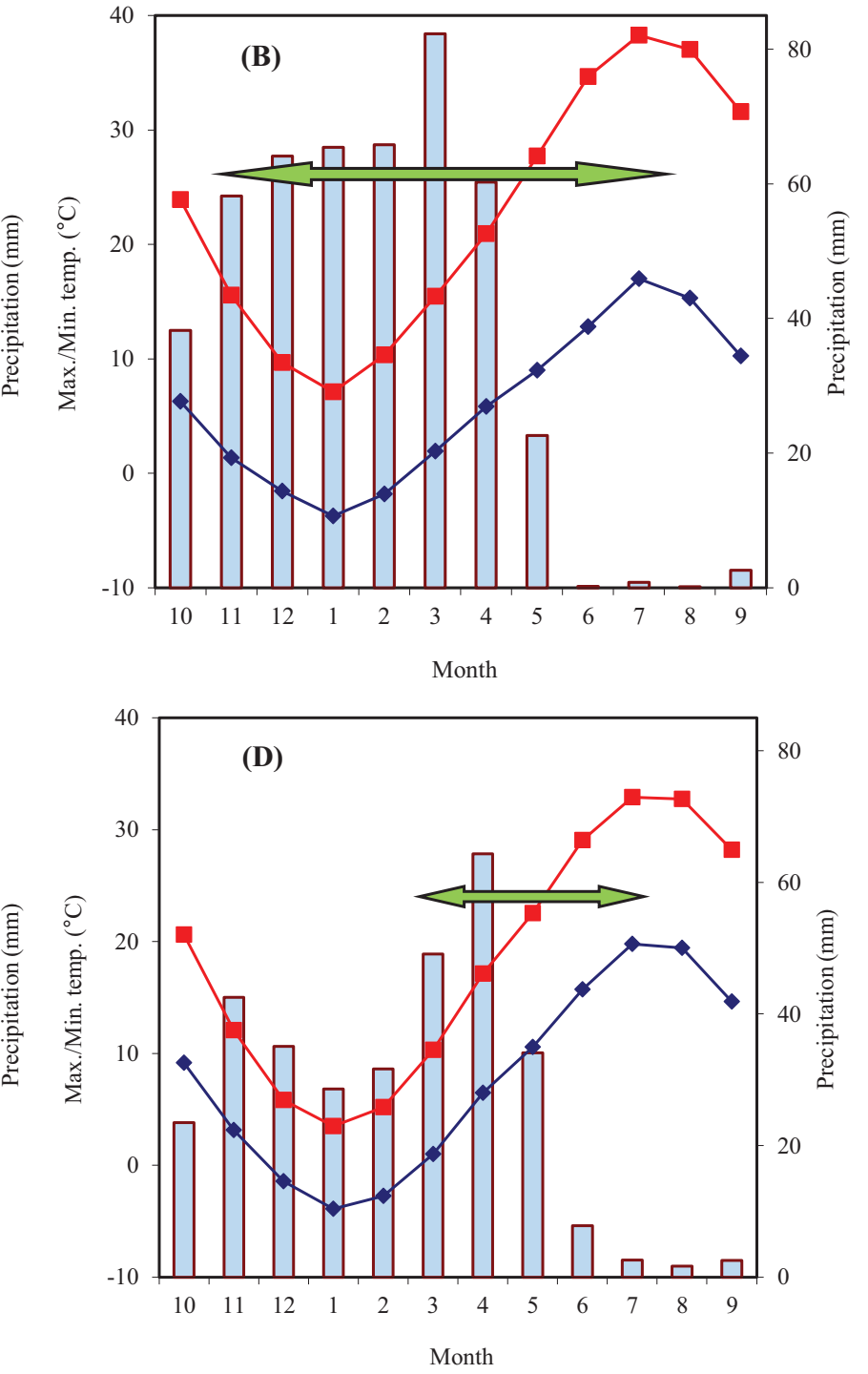

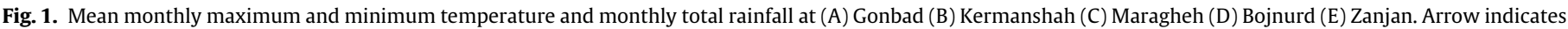
the growing season of chickpea at the locations. 
Table 2

Potential yield, water-limited potential yield, actual yield and yield gap at the selected location. Weighted mean indicates country mean.

\begin{tabular}{|c|c|c|c|c|c|c|c|}
\hline & $\begin{array}{l}\text { Location } \\
\text { Gonbad }\end{array}$ & Kermanshah & Maragheh & Bojnurd & Zanjan & Average & Weighed mean \\
\hline \multicolumn{8}{|l|}{ Potential yield $\left(Y_{\mathrm{p}}\right)$} \\
\hline Average (kg/ha) & 3995 & 4353 & 4037 & 3743 & 3188 & 3863 & 3973 \\
\hline Range & $3661-4221$ & $3728-4758$ & $3584-4489$ & $3243-4130$ & $2862-3436$ & - & - \\
\hline $\mathrm{CV}(\%)$ & 3.9 & 8.5 & 6.0 & 7.7 & 6.1 & 6.4 & 6.1 \\
\hline \multicolumn{8}{|l|}{ Water-limited potential yield $\left(Y_{\mathrm{w}}\right)$} \\
\hline Average $(\mathrm{kg} / \mathrm{ha})$ & 1565 & 712 & 1019 & 638 & 800 & 947 & 991 \\
\hline Range & $731-2381$ & $436-1176$ & $315-2363$ & $127-1469$ & $487-1178$ & - & - \\
\hline $\mathrm{CV}(\%)$ & 40 & 32 & 49 & 56 & 27 & 41 & 46 \\
\hline$Y_{\mathrm{w}} / \mathrm{Y}_{\mathrm{p}} \times 100$ & 39 & 16 & 25 & 17 & 25 & 25 & 25 \\
\hline Yield loss due to terminal drought $\left[\left(1-\left(Y_{\mathrm{w}} / \mathrm{Y}_{\mathrm{p}}\right)\right) \times 100 ; \%\right]$ & 61 & 84 & 75 & 83 & 75 & 75 & 75 \\
\hline \multicolumn{8}{|l|}{ Actual yield $\left(Y_{\mathrm{a}}\right)$} \\
\hline Average (kg/ha) & 797 & 452 & 554 & 312 & 308 & 485 & 528 \\
\hline Range & $500-1068$ & $227-712$ & $319-967$ & $159-431$ & $58-420$ & - & - \\
\hline $\mathrm{CV}(\%)$ & 22 & 31 & 34 & 29 & 34 & 30 & 33 \\
\hline Yield gap $\left(Y_{\mathrm{g}} ; Y_{\mathrm{w}}-Y_{\mathrm{a}}\right)$ & 768 & 260 & 465 & 326 & 492 & 462 & 463 \\
\hline Relative yield $\left(Y_{\mathrm{a}} / Y_{\mathrm{w}} \times 100\right)$ & 51 & 64 & 54 & 49 & 38 & 51 & 53 \\
\hline Relative gap $\left(Y_{\mathrm{g}} / Y_{\mathrm{w}} \times 100\right)$ & 49 & 36 & 46 & 51 & 62 & 49 & 47 \\
\hline Yield increase with $80 \%$ coverage $\left[\left(\left(0.80 \times Y_{\mathrm{w}} / Y_{\mathrm{a}}\right)-1\right) \times 100 ; \%\right]$ & 57 & 26 & 47 & 64 & 108 & 56 & 50 \\
\hline
\end{tabular}

had the highest $Y_{a}$ with an average of $797 \mathrm{~kg} \mathrm{ha}^{-1}$. The average yield for other locations, in descending order were $554 \mathrm{~kg} \mathrm{ha}^{-1}$ for Maragheh, $452 \mathrm{~kg} \mathrm{ha}^{-1}$ for Kermanshah, $312 \mathrm{~kg} \mathrm{ha}^{-1}$ for Bojnord and $308 \mathrm{~kg} \mathrm{ha}^{-1}$ for Zanjan (Table 2). Average yield across locations was $485 \mathrm{~kg} \mathrm{ha}^{-1}$ and weighted average was $528 \mathrm{~kg} \mathrm{ha}^{-1}$. Higher yields at Gonbad were due to higher rainfall and a less intensive terminal drought at this location. While chickpea was autumn-sown in Kermanshah, crop yield was lower because of the lower rainfall and somewhat higher temperatures during grain filling period at this location (Fig. 1). Crop management practice had also an important role in determination of $Y_{\mathrm{a}}$ that will be discussed later.

\subsection{Yield gap $\left(\mathrm{Y}_{g}\right)$}

Estimated $Y_{\mathrm{g}}$ varied between 260 and $768 \mathrm{~kg} \mathrm{ha}^{-1}$ with a country average of about $460 \mathrm{~kg} \mathrm{ha}^{-1}$ (Table 2). $Y_{\mathrm{g}}$ was $36-62 \%$ of $Y_{\mathrm{w}}$ depending on location with a weighted mean of $47 \%$. In Bojnord and Zanjan, farmers hardly reached $50 \%$ of the $Y_{\mathrm{w}}$ of their locations. Although Gonbad had the highest $Y_{\mathrm{a}}$, it also had the highest $Y_{\mathrm{g}}$ of $768 \mathrm{~kg} \mathrm{ha}^{-1}\left(49 \%\right.$ of $\left.Y_{\mathrm{w}}\right)$ due to high $Y_{\mathrm{w}}$ of the location (Table 2$)$. The highest $Y_{\mathrm{g}}$ as percentage of $Y_{\mathrm{w}}(62 \%)$ was obtained for Zanjan (equal to $492 \mathrm{~kg} \mathrm{ha}^{-1}$ ) (Table 2). Fig. 3 compares the locations with respect to $Y_{\mathrm{g}}$.

\subsection{Increase of potential yield}

A single irrigation of $60 \mathrm{~mm}$ at first-pod increased average yield potential from $947 \mathrm{~kg} \mathrm{ha}^{-1}\left(Y_{\mathrm{w}}\right)$ under rainfed conditions to $1672 \mathrm{~kg} \mathrm{ha}^{-1}\left(Y_{\mathrm{i}}\right)$, which means a $77 \%$ increase (Table 3; Fig. 2). Average $Y_{\mathrm{i}}$ varied from $1286 \mathrm{~kg} \mathrm{ha}^{-1}$ at Kermanshah to $2240 \mathrm{~kg} \mathrm{ha}^{-1}$ at Gonbad. CV of grain yield declined from $41 \%$ to $24 \%$ by this single irrigation (Table 3). Comparing actual farmers' yield with $Y_{\mathrm{i}}$ indicated $Y_{\mathrm{g}}$ ranged from $834 \mathrm{~kg} \mathrm{ha}^{-1}$ (Kermanshah) to $1443 \mathrm{~kg} \mathrm{ha}^{-1}$ (Gonbad). Farmers' yields are $21-36 \%$ of the $Y_{\mathrm{i}}$ values with an average of $29 \%$ across locations (Fig. 3 ).

Using short duration cultivars increased water-limited potential yield from $947 \mathrm{~kg} \mathrm{ha}^{-1}\left(Y_{\mathrm{w}}\right)$ to $1179 \mathrm{~kg} \mathrm{ha}^{-1}\left(Y_{\mathrm{e}}\right)$. Yield potential of the earlier cultivars under rainfed conditions $\left(Y_{\mathrm{e}}\right)$ varied from $759 \mathrm{~kg} \mathrm{ha}^{-1}$ in Bojnord to $1854 \mathrm{~kg} \mathrm{ha}^{-1}$ in Gonbad (Table 3; Fig. 2). The greatest yield increase was observed for Kermanshah (50\%). Using earlier cultivars resulted in a reduction of yield variability that can be seen in lower predicted CVs; from $27-56 \%$ to $23-46 \%$ (Table 3).
Average across locations, a combination of using earlier cultivars plus applying a single irrigation of $60 \mathrm{~mm}$ at first-pod increased potential yield under rainfed conditions $\left(Y_{\mathrm{w}}\right)$ from $947 \mathrm{~kg} \mathrm{ha}^{-1}$ to $1926 \mathrm{~kg} \mathrm{ha}^{-1}\left(Y_{\mathrm{ie}}\right)$ (Table 3; Fig. 3). The lowest increase was predicted for Gonbad (70\%) and the highest (147\%) for Bojnord. The CV of grain yield declined by $5-32 \%$. Median yield moved from $544-1543$ to $1427-2730 \mathrm{~kg} \mathrm{ha}^{-1}$ (Fig. 2).

Actual farmers' yields were $18-30 \%$ of $Y_{\text {ie }}$ (yield potential under conditions of using shorter duration cultivars plus applying a single irrigation of $60 \mathrm{~mm}$ at first-pod) with an average gap of $1442 \mathrm{~kg} \mathrm{ha}^{-1}$ (Table 3; Fig. 3). Using a combination of earlier cultivars and a single irrigation of $60 \mathrm{~mm}$ at first-pod and assuming that farmers' reach $80 \%$ of the predicted $Y_{\text {ie }}$, crop yield increases of 167\% (Gonbad)-303\% (Bojnord) would be anticipated. The average yield increase was $218 \%$ across location and country average yield increase of $202 \%$ was predicted, which means tripling chickpea production in the country.

\section{Discussion}

\subsection{Yield gap}

All chickpea producing areas of Iran are facing terminal drought stress (Fig. 1; Soltani et al., 2001, 2005, 2006; Sabaghpour et al., 2006; Soltani and Sinclair, 2012b; Kanouni et al., 2012). This drought hugely affects crop yield and its variability (Table 2; Fig. 2) Water-limited potential yield $\left(Y_{\mathrm{w}}\right)$ was $25 \%$ of potential yield with no water-limitation $\left(Y_{\mathrm{p}}\right)$ and its variability increased seven times. Soltani et al. (2001) showed that terminal drought stress started at a time between flowering and the beginning seed growth of chickpea in Maragheh. They also indicated that the terminal drought stress reduced grain yield by $67 \%$, from $2766 \mathrm{~kg} \mathrm{ha}^{-1}$ under fullirrigated conditions $\left(Y_{\mathrm{p}}\right)$ to $909 \mathrm{~kg} \mathrm{ha}^{-1}$ under rainfed conditions $\left(Y_{\mathrm{w}}\right)$. Experimentally, Silim and Saxena (1993) working in north of Syria with 14 chickpea cultivars during three seasons, showed terminal drought stress reduced yield by $61 \%$.

Average actual country yield $\left(Y_{\mathrm{a}}\right)$ was $53 \%$ of the simulated country $Y_{\mathrm{w}}$ (Table 2; Fig. 2; Fig. 3). This means that farmers had reached 53\% (range: $38-64 \%$ ) of water-limited potential yield $\left(Y_{\mathrm{w}}\right)$. Some reasons of low farm yields and high yield gap might be: inefficient methods used for seed-bed preparation and sowing, inefficient soil water management, yield losses due to weeds, pests and diseases in farmers' fields, and low soil fertility or inadequate nutrient management. Rassam and Soltani (2007) indicated that soil water content 

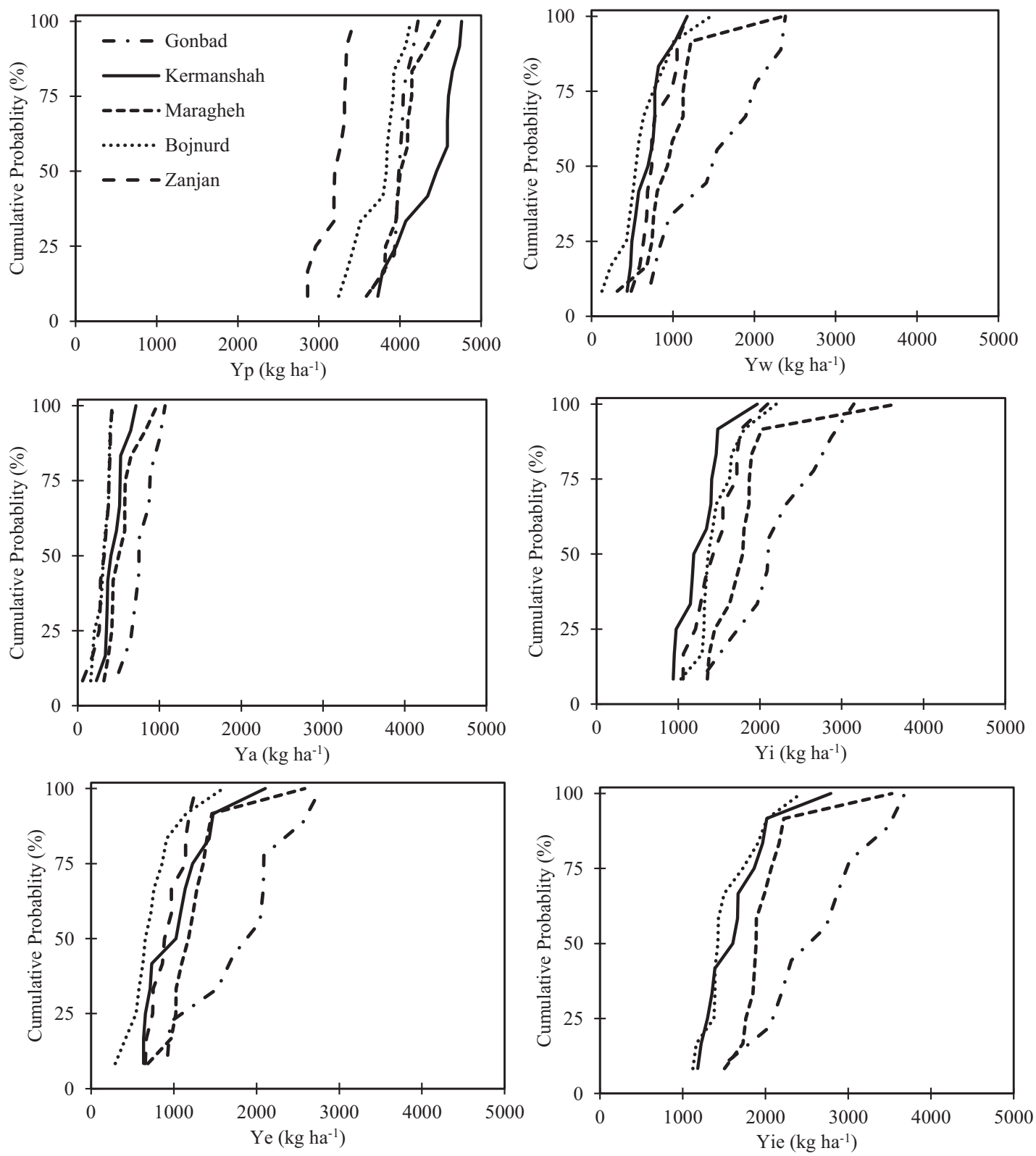

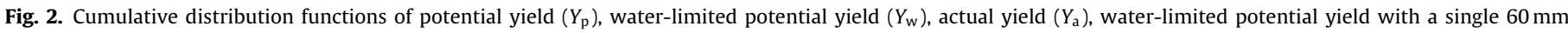

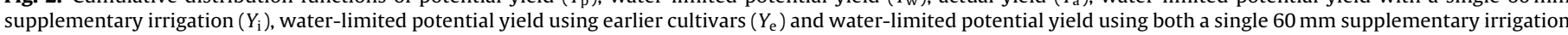
and earlier cultivars $\left(Y_{\mathrm{ie}}\right)$ at the selected locations.

at sowing time was a very important determinant of chickpea yield under rainfed conditions of Maragheh. Traditional tillage, using mould-board plough and disking, are still very common in chickpea producing areas of Iran. Based on local experience, the authors think attempts to replace the current traditional tillage practice by conservation tillage and conservation agriculture along with earlier sowing and improving pest management are key factors in increasing water productivity and yield of chickpea. However, governmental investment/subsidy will be required to provide farmers with the required machines and equipment.

If farmers could reach $80 \%$ of water-limited potential yield of their locations, they could enjoy yield increases of $26-108 \%$; with an average of $56 \%$ (Table 2 ). Then, the weighted mean, an indication of country average, would increase by $50 \%$, from 528 to $793 \mathrm{~kg} \mathrm{ha}^{-1}$. This is an important finding as indicates great potential exists to boost chickpea yield in Iran and probably other similar developing countries in West Asia and North Africa (WANA) region. Quantify- ing the yield gap and identifying regions with greatest potential to increase food supply is critical for sustainable intensification and improvement of the world food security (van Ittersum et al., 2013). This is also vital to inform policies and prioritize research to achieve food security without environmental degradation (van Wart et al., 2013).

Recently, Amiri Deh Ahmadi et al. (2014) estimated a yield gap of 72-85\% for rainfed chickpea in Razavi Khorasan, a province in the north-east of Iran that produces $1 \%$ of country production. Figures obtained in the present study for chickpea are comparable to those reported for wheat crops in Iran. Gharineh et al. (2012) estimated yield gap of 40-65\% for wheat in Khuzestan province in southwest of the country. Nassiri and Koocheki (2009) reported yield gaps of $58-62 \%$ for wheat in Khorasan province located in the north-east of the country. Mueller et al. (2012) reported an average yield gap of $40 \%$ for wheat in Iran. 

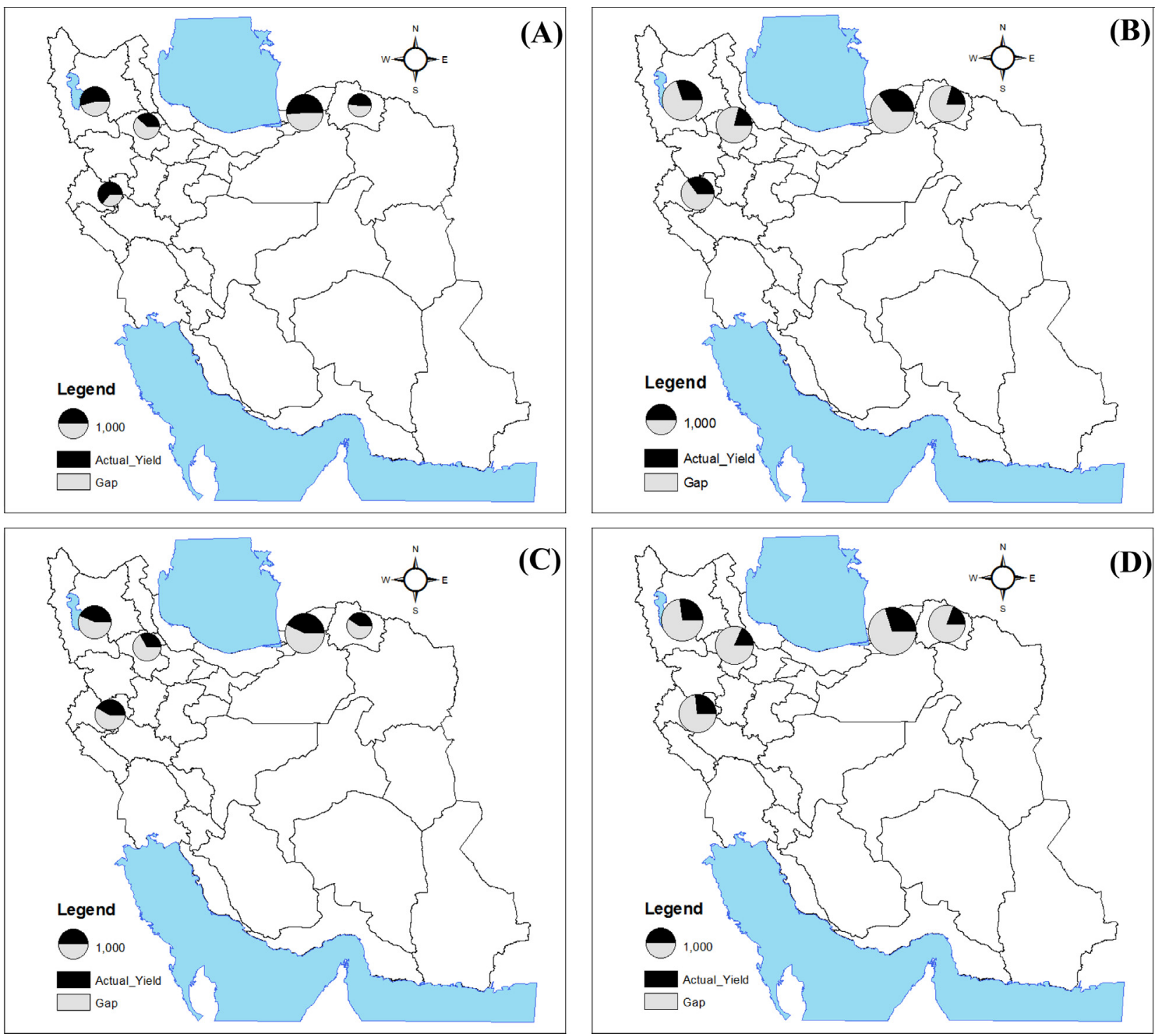

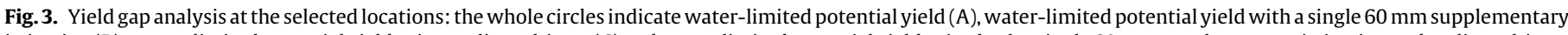

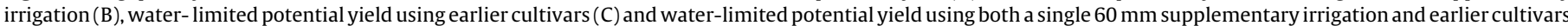
(D) at the selected locations. The dark portion of each circle indicates actual yield and the white portion indicates yield gap.

\subsection{Increasing water-limited potential yield}

If we consider the farmers yields as $Y_{\mathrm{a}}=Y_{\mathrm{w}}-Y_{\mathrm{g}}$, then another approach to increase $Y_{\mathrm{a}}$ would be increase of $Y_{\mathrm{w}}$. A single irrigation of $60 \mathrm{~mm}$ at first-pod increased $Y_{\mathrm{w}}$ by $77 \%$ and decreased its CV by 41\% (Table 3; Fig. 2). Soltani et al. (2001) estimated that a single irrigation could increase chickpea yield at Maragheh by $56-89 \%$ depending on the time of application (first- flower or first-seed). Vadez et al. (2012) indicated that a single irrigation of $30 \mathrm{~mm}$ (with an efficiency of $100 \%$ ) would increase chickpea yield by $20-40 \%$ (average 29\%) across fourteen locations in India.

Current farmers' yields under rainfed conditions are about $29 \%$ of water-limited potential yield with a single irrigation $\left(Y_{\mathrm{i}}\right)$ (Fig. 3). Assuming farmers could apply this single irrigation and reach $80 \%$ of $Y_{\mathrm{i}}$, a country (weighted) average yield increase of $173 \%$ was estimated (Table 3 ). Another assumption for obtaining the figures is that water is the main limiting factor but in order to reach $80 \%$ of $Y_{\mathrm{i}}$, farmers need to accompany the irrigation with other agronomic management aspects. A single irrigation of $60 \mathrm{~mm}$ might be feasible via water saving from improvement of water management practice. It has been estimated that irrigation efficiency is indeed very low (30-35\%) in Iran (Alizadeh and Keshavarz, 2005), and large improvement of these figures would be possible. In additions, our results indicate the productivity of the single irrigation water in chickpea would be very high [ $\left.(1804-991) / 60=13.6 \mathrm{~kg} \mathrm{ha}^{-1} \mathrm{~mm}^{-1}\right]$ and should be compared with the productivity of the same amount of water in current irrigated crops. The outcome of such comparisons might lead to a slight reduction of the irrigation (deficit irrigation) of crops like sugar beet towards the partial irrigation of crops like chickpea. Foley et al. (2011) and Mueller et al. (2012) stated that redistributing water and nutrients imbalances could largely close yield gap.

Using short duration cultivars increased water-limited potential yield by $25 \%$. (Table 3; Fig. 2). The result is inline of what predicted by Soltani and Sinclair (2012b) for chickpea in Tabriz (a location close to Maragheh) and Gonbad. They predicted that using earlier cultivars with $20 \%$ shorter duration from emergence to flowering would increase crop yield by about $14 \%$ and the CV of gain yield would decrease by $12 \%$. They showed that yield increased in $97 \%$ of the seasons in Tabriz and 90\% of the seasons in Gonbad. They 
Table 3

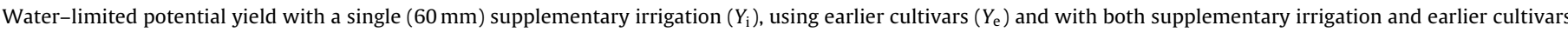
$\left(Y_{\mathrm{ie}}\right)$ and related yield gap at the selected locations. Weighted mean is an estimationof country mean.

\begin{tabular}{|c|c|c|c|c|c|c|c|}
\hline & \multicolumn{5}{|l|}{ Location } & \multirow[t]{2}{*}{ Average } & \multirow[t]{2}{*}{ Weighed mean } \\
\hline & Gonbad & Kermanshah & Maragheh & Bojnord & Zanjan & & \\
\hline \multicolumn{8}{|l|}{ Potential yield with supplementary irrigation $\left(Y_{\mathrm{i}}\right)$} \\
\hline Average $(\mathrm{kg} / \mathrm{ha})$ & 2240 & 1286 & 1871 & 1486 & 1479 & 1672 & 1804 \\
\hline Range & $1356-3148$ & 936-1967 & $1355-3685$ & 1033-2199 & $1060-2093$ & - & - \\
\hline $\mathrm{CV}(\%)$ & 26 & 23 & 33 & 20 & 21 & 24 & 30 \\
\hline $\begin{array}{l}\text { Increase in potential yield by supplementary irrigation } \\
{\left[\left(Y_{\mathrm{i}}-Y_{\mathrm{w}}\right) / Y_{\mathrm{w}} \times 100\right]}\end{array}$ & 43 & 81 & 84 & 133 & 85 & 77 & 85 \\
\hline Yield gap $\left(Y_{\mathrm{g}} ; Y_{\mathrm{i}}-Y_{\mathrm{a}}\right)$ & 1443 & 834 & 1317 & 1174 & 1172 & 1188 & 1275 \\
\hline Relative yield $\left(Y_{\mathrm{a}} / Y_{\mathrm{i}} \times 100\right)$ & 36 & 35 & 30 & 21 & 21 & 29 & 29 \\
\hline Relative gap $\left(Y_{\mathrm{g}} / Y_{\mathrm{i}} \times 100\right)$ & 64 & 65 & 70 & 79 & 79 & 71 & 71 \\
\hline Yield increase with $80 \%$ coverage $\left[\left(\left(0.80 \times Y_{\mathrm{i}} / Y_{\mathrm{a}}\right)-1\right) \times 100 ; \%\right]$ & 125 & 127 & 170 & 281 & 285 & 176 & 173 \\
\hline \multicolumn{8}{|l|}{ Water-limited potential yield with earlier cultivars $\left(Y_{\mathrm{e}}\right)$} \\
\hline Average $(\mathrm{kg} / \mathrm{ha})$ & 1854 & 1071 & 1274 & 759 & 939 & 1179 & 1237 \\
\hline Range & $926-2776$ & $634-2107$ & $688-2582$ & $688-1462$ & $656-1268$ & - & - \\
\hline $\mathrm{CV}(\%)$ & 35 & 42 & 36 & 46 & 23 & 36 & 36 \\
\hline $\begin{array}{l}\text { Increase in potential yield by using shorter duration cultivars } \\
{\left[\left(Y_{\mathrm{e}}-\mathrm{Y}_{\mathrm{w}}\right) / \mathrm{Y}_{\mathrm{w}} \times 100\right]}\end{array}$ & 18 & 50 & 25 & 19 & 17 & 25 & 25 \\
\hline Yield gap $\left(Y_{\mathrm{g}} ; Y_{\mathrm{e}}-Y_{\mathrm{a}}\right)$ & 1057 & 619 & 720 & 447 & 631 & 695 & 709 \\
\hline Relative yield $\left(Y_{\mathrm{a}} / Y_{\mathrm{e}} \times 100\right)$ & 43 & 42 & 43 & 41 & 33 & 41 & 43 \\
\hline Relative gap $\left(Y g / Y_{\mathrm{e}} \times 100\right)$ & 57 & 58 & 57 & 59 & 67 & 59 & 57 \\
\hline Yield increase if $80 \%$ coverage $\left[\left(\left(0.80 \times \mathrm{Y}_{\mathrm{e}} / \mathrm{Y}_{\mathrm{a}}\right)-1\right) \times 100 ; \%\right]$ & 86 & 89 & 84 & 95 & 144 & 95 & 87 \\
\hline \multicolumn{8}{|l|}{ Potential yield with earlier cultivars plus supplementary irrigation $\left(Y_{\mathrm{ie}}\right)$} \\
\hline Average $(\mathrm{kg} / \mathrm{ha})$ & 2657 & 1669 & 2039 & 1574 & 1692 & 1926 & 1997 \\
\hline Range & $1562-3685$ & $1183-2789$ & $1505-3528$ & $1121-2427$ & $1139-2132$ & - & - \\
\hline $\mathrm{CV}(\%)$ & 26 & 27 & 25 & 24 & 21 & 25 & 25 \\
\hline $\begin{array}{l}\text { Increase in potential yield by using shorter duration cultivars plus } \\
\text { supplementary irrigation } \\
{\left[\left(Y_{\mathrm{ie}}-Y_{\mathrm{w}}\right) / Y_{\mathrm{w}} \times 100\right]}\end{array}$ & 70 & 134 & 100 & 147 & 112 & 103 & 104 \\
\hline Yield gap $\left(Y_{\mathrm{g}} ; Y_{\mathrm{ie}}-Y_{\mathrm{a}}\right)$ & 1860 & 1217 & 1485 & 1262 & 1385 & 1442 & 1469 \\
\hline Relative yield $\left(Y_{\mathrm{a}} / Y_{\mathrm{ie}} \times 100\right)$ & 30 & 27 & 27 & 20 & 18 & 25 & 26 \\
\hline Relative gap $\left(Y_{\mathrm{g}} / Y_{\mathrm{ie}} \times 100\right)$ & 70 & 73 & 73 & 80 & 82 & 75 & 74 \\
\hline Yield increase if $80 \%$ coverge $\left[\left(\left(0.80 \times \mathrm{Y}_{\mathrm{ie}} / \mathrm{Y}_{\mathrm{a}}\right)-1\right) \times 100 ; \%\right]$ & 167 & 195 & 194 & 303 & 340 & 218 & 202 \\
\hline
\end{tabular}

also indicated that early maturity via shorter grain filling period was fruitless. The difference between the figures and those found here is due to different time periods used for simulation in that study and the current study. The reason of yield increase is due to shifting the growth period of the crop away from the late-season terminal drought (Soltani and Sinclair, 2012b; Singh et al., 2014), and therefore the avoidance of the severe terminal, water-deficit period allowing increased yield. A shorter vegetative period results in saving water for later use during grain filling period.

Experimental results also support the conclusion; Silim and Saxena (1993) in Syria, Sabaghpour et al. (2006) in Iran, and Berger et al. $(2004,2006)$ in India and Australia reported increased yield using earlier cultivars due to escape from terminal drought stress. There are also chickpea cultivars with a wide range of duration from traditional varieties with $>110$ days to maturity to breeding lines with extra-early maturity with $<75$ days to maturity, which makes using earlier cultivars a feasible option for yield increase (Gaur et al., 2008). The results here and previous results advocate for an urgent need for the chickpea breeding programs in Iran to develop earlymaturing cultivars. However, as stated by Hall and Richards (2013) and Meng et al. (2013) increased production per unit area through the genetic improvement is very difficult in a short period of time. It should be noted that developing shorter-duration cultivars approximately takes 10-15 years, however, this period can be shortened to 5-7 years by back-crossing and transferring the responsible genes to the current cultivars.

A key finding of the study was that much higher yield increase were possible via an agronomic option (77\% increase in $Y_{\mathrm{w}}$ ) than via a genetic improvement option (25\% increase in $Y_{\mathrm{w}}$ ). In other words, replacement of the current cultivars with shorter-duration cultivars by plant breeding measures would increase actual yield by $25 \%$ (assuming current relative yield of 53\% - Table 2), whereas bridging the yield gap of the current cultivars by $80 \%$ using agronomy practice would result in $50 \%$ increase in actual yield. Thus, we can argue that chickpea yield in Iran and similar regions are largely limited by inefficient use of environmental resources (mainly water) and not the genetics of the current cultivars. Similarly, the greatest increase in actual yield depends on improving agronomy practice. In the past decades, much emphasis has been put on plant genetics and breeding to increase crop yield while seeking the best agronomy practice to close yield gap has been largely neglected. George (2014) stated that the focus must shift from relying mainly on germplasm-driven increases in total production to increasing $Y_{\mathrm{a}}$ and productivity of inputs through effective agronomy practice. Similar statements was made by Vadez et al. (2012) who showed that while $30 \mathrm{~mm}$ of irrigation at first-seed stage (R5) would increase yield by $29 \%$ on average, the best genetic trait to improve soil water capture would hardly increase yield by $10 \%$. Thus, searching best agronomy practice in order to close the yield gap should be brought into the focus.

Our results also confirm the statement that the greatest agronomic opportunity to increase global food security lies in developing countries (van Ittersum et al., 2013; George, 2014). Similar assessments need to be done in other developing countries in WANA region. However, developing countries farmers do not adopt improved agronomic operations unless there will be the prospect of making profits with lower risk (George, 2014). Therefore, efforts should be made to demonstrate these potential gains experimentally. Also, plans should be developed to supply the needed irrigation. Optimal crop management practice will also be significantly cleaner for the environment; it will decrease input required for crop production and its resultant footprint and the pressure on the natural resources (Foley et al., 2011; Smith, 2013; Soltani et al., 2013, 2014). For instance, Soltani et al. (2014) showed that 
in rainfed canola a better crop management production scenario was significantly more efficient and cleaner for the environment. The scenario consumed 25\% less input energy, needed $17 \%$ lower amount of nitrogen fertilizer, but resulted in 35\% more grain yield and output energy. This scenario also resulted in $26 \%$ less greenhouse gases (GHG) emissions per unit field area and 45\% less GHG emissions per ton of grain.

Combination of using earlier cultivars plus applying a single irrigation of $60 \mathrm{~mm}$ at first-pod increased potential yield under rainfed conditions $\left(Y_{\mathrm{w}}\right)$ by $104 \%$ and decreased $\mathrm{CV}$ of grain yield from $46 \%$ to 25\% (Table 2; Fig. 2; Fig. 3). Sinclair and Rufty (2012) stated that while improving plant genetics is frequently viewed as the path to increase crop yields, yield increase most often obtain from combination of improved cultivars and increase availability of nitrogen and water resources. The finding that combination of earlier cultivars and a single irrigation results in yield increase may be somewhat contradictory as short duration cultivars are set for those situations where water is limiting. Intuitively, if some irrigation is possible, it would be expected that longer duration cultivars would perform better. Simulations testing longer duration cultivars showed that even with a single irrigation, shorter duration cultivars performed better (data not shown). Therefore even with a single irrigation, shorter-durations would be better for Iran's conditions.

Crop simulation models have been known as best tools to estimate $Y_{\mathrm{p}}$ or $Y_{\mathrm{w}}$ in yield gap analysis (Lobell et al., 2009; van Ittersum et al., 2013). The models can account for genotype $\times$ environment $\times$ management interactions, but they need to be tested rigorously across different environments and managements. The crop models substitute field surveys and measurements that are used to estimate $Y_{\mathrm{p}}$ or $Y_{\mathrm{w}}$ and need lots of time, budget and work. van Ittersum et al. (2013) listed the desirable attributes of crop simulation models for use in yield gap assessment; the model used in this study has all the key attributes (please see the references cited in Section 2.3). The current research demonstrates the value of crop models in yield gap studies. A well-tested crop model was applied straightforward to estimate yield potentials under optimal and limited water conditions and to find possible routes to promote water-limited potential yield at country level. Bhatia et al. (2008), Hochman et al. (2013), Lu and Fan (2013) and Meng et al. (2013) have also applied crop models to quantify $Y_{\mathrm{p}}$ and $Y_{\mathrm{w}}$ in their analyses.

\section{Concluding remarks}

(1) High yield gaps were found in chickpea in Iran that probably exist in other developing countries in the WANA region. By improving agronomy practice and assuming farmers can reach $80 \%$ of the water-limited yield potential, an increased country production of about 50\% (from 528 to $790 \mathrm{~kg} \mathrm{ha}^{-1}$ ) was predicted. Therefore, a great capacity exists to promote food production and lessen food security issue by closing yield gap in the region.

(2) There are still big rooms to increase water-limited potential yield of chickpea by breeding for simple, single traits like earliness. Substituting current cultivars with short duration cultivars with $20 \%$ shorter vegetative period would promote water-limited potential yield by $25 \%$. This potential need to be tested in other parts of WANA region.

(3) Agronomy measures were more effective than the plant breeding measures to increase the country actual yield, $50 \%$ versus $25 \%$. Searching best agronomy practice, therefore, needs to be brought into the focus to bridge yield gaps and for ecological intensification.
(4) Invoking best agronomy practice is also very effective in increasing water-limited potential yield. Application of a single irrigation of $60 \mathrm{~mm}$ increases country average $Y_{\mathrm{w}}$ by $85 \%$ (from 991 to $1804 \mathrm{~kg} \mathrm{ha}^{-1}$ ). Accompanying this single irrigation with shorter-duration cultivars increased $Y_{\mathrm{w}}$ by $104 \%$ (from 991 to $1997 \mathrm{~kg} \mathrm{ha}^{-1}$ ). Research efforts are required to find the best cultivation pattern in the region with respect to water use and distribution. It seems devoting limited water resources to supplementary (limited) irrigation of crops like chickpea would be more fruitful than growing full-irrigated crops with a high irrigation demand.

(5) It was predicted that if farmers could apply a single irrigation of $60 \mathrm{~mm}$ at first-pod and reach $80 \%$ of $Y_{\mathrm{w}}$, country yield would increase by $173 \%$ (from 528 to $1442 \mathrm{~kg} \mathrm{ha}^{-1}$ ). Similarly, it was estimated that combination of a single irrigation plus shorter cultivars and closing yield gap by $80 \%$ would result in country yield increase of $202 \%$ (from 528 to $1598 \mathrm{~kg} \mathrm{ha}^{-1}$ ). Thus, tripling chickpea production would be feasible. Although not simple, showing the worthiness via experimental confirmation is needed and evaluating the potential of finding sufficient irrigation is necessary. To bridge yield gap and achieve higher production focus must be on improved agronomic management. This should be considered in making policies, prioritizing research and rationing the research budget.

\section{Appendix A.}

The results of SSM-Chickpea robustness test. The first figure indicates simulated versus measured grain yield of chickpea across Iran as reported by Soltani and Sinclair (2011). The second figure shows simulated versus measured grain yield for a line-source experiment in India as reported by Vadez et al. (2012).
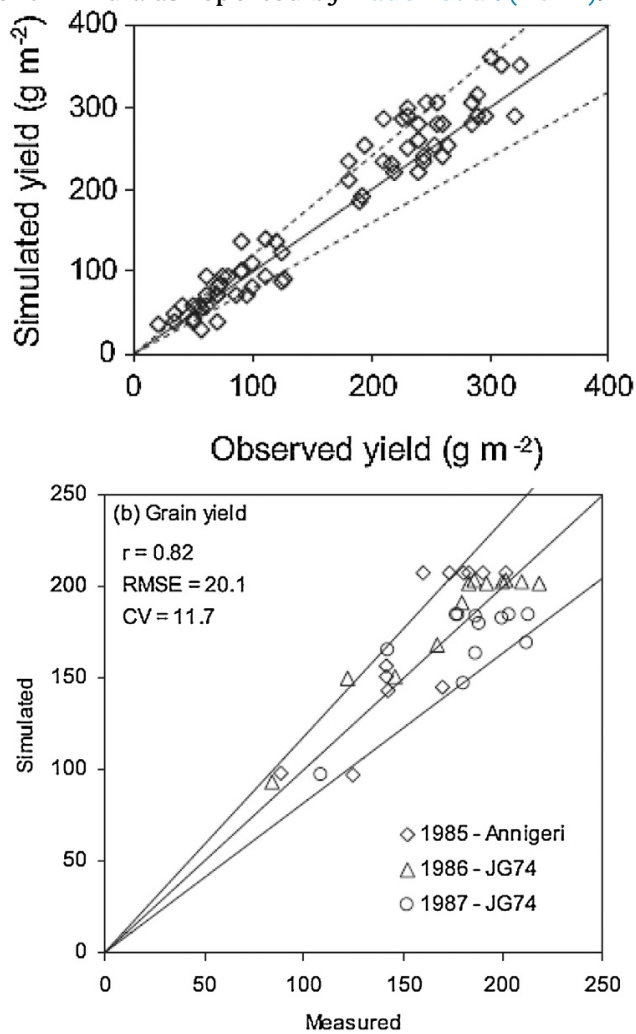


\section{References}

Akibode, S., Maredia, M., 2011. Global and regional trends in production, trade and consumption of food legume crops. SPIA Report, Department of Agricultural, Food and Resource Economics Michigan State University MI.

Alberda, T., 1962. Actual and potential production of agricultural crops. Neth. J. Agric. Sci. 10, 325-332.

Ali, M., Gupta, S., 2012. Carrying capacity of Indian agriculture: pulse crops. Curr. Sci. 102, 874-881.

Alizadeh, A., Keshavarz, A., 2005. Status of agricultural water use in Iran. Water Conservation, Reuse, and Recycling: Proceedings of an Iranian-American Workshop, 2005

Amiri Deh Ahmadi, S.R., Parsa, M., Bannayan Aval, M., Nassiri Mahallati, M. Deihimfard, R., 2014. Yield gap analysis of chickpea under semi-arid conditions: a simulation study. Int. J. Plant Prod. 8, 531-548.

Anonymous. 2013. Agricultural statistic. Volume 1: Crops. Jahad ministry of agriculture. Planning and economic affairs, office of statistics and information technology.

Berger, J.D., Turner, N.C., Siddique, K.H.M., Knights, E.J., Brinsmead, R.B., Mock, I., Edmondson, C., Khan, T.N., 2004. Genotype by environment studies across Australia reveal the importance of phenology for chickpea (Cicer arietinum $\mathrm{L}$ ) improvement. Aust. J. Agric. Res. 55, 1071-1084.

Berger, J.D., Ali, M., Basu, P.S., Chaudhary, B.D., Chaturvedi, S.K., Deshmukh, P.S., Dharmaraj, P.S., Dwivedi, S.K., Gangadhar, G.C., Gaur, P.M., Kumar, J., Pannu, R.K., Siddique, K.H.M., Singh, D.N., Singh, D.P., Singh, S.J., Turner, N.C., Yadava, H.S., Yadav, S.S., 2006. Genotype by environment studies demonstrate the critical role of phenology in adaptation of chickpea (Cicer arietinum L.) to high and low yielding environments of India. Field Crops Res. 98, 230-244.

Bhatia, V., Singh, P., Wani, S., Rao, A.K., Srinivas, K., 2006. Yield gap analysis of soybean, groundnut, pigeonpea and chickpea in India using simulation modeling. Global Theme on Agroecosystems Report No. 31.

Bhatia, V.S., Singh, P., Wani, S.P., Chauhan, G.S., Rao, A.V.R.K., Mishra, A.K., Srinivas, K., 2008. Analysis of potential yields and yield gaps of rainfed soybean in India using CROPGRO-soybean model. Agric. For. Meteorol. 148, 1252-1265.

Bruinsma, J., 2009. The resource outlook to 2050: by how much do lamd, water and crop yields meed to increase by 2050? FAO Expert Meeting on How to Feed the World in 2050. Rome.

Cassman, K.G., 2012. What do we need to know about global food security? Glob. Food Secur. 1, 81-82.

Dewan, M.L., Famouri, J., 1964. The soils of Iran. Food and Agriculture Organization of the United Nations (FAO), Rome Italy, $319 \mathrm{p}$

FAO (2009) Global agriculture towards 2050. Rome, FAO.

FAO, 2012. Statistical Databases. Food and Agriculture Organization of the United Nations http://faostat3.fao.org.

Foley, J.A., Ramankutty, N., Brauman, K.A., Cassidy, E.S., Gerber, J.S., Johnston, M., Mueller, N.D., O'Connell, C., Ray, D.K., West, P.C., 2011. Solutions for a cultivated planet. Nature 478, 337-342.

Gaur, P.M., Krishnamurphy, L., Kashiwagi, J., 2008. Improving drought-avoidance root traits in chickpea (Cicer arietinum L.) - current status of research at ICRISAT. Plant Prod. Sci. 11 (1), 3-11.

George, T., 2014. Why crop yields in developing countries have not kept pace with advances in agronomy. Glob. Food Secur. 3, 49-58.

Gharineh, M.H., Bakhshandeh, A., Andarzian, B., Fayazizadeh, N., 2012. Agroclimatic zoning of Khuzestan province for potential yield wheat using WOFOST model. J. Agroecol. 4, 255-264 (In persian with English abstract)

Hall, A.J., Richards, R.A., 2013. Prognosis for genetic improvement of yield potential and water-limited yield of major grain crops. Field Crops Res. 143, 18-33.

Hochman, Z., Gobbett, D., Holzworth, D., McClelland, T., van Rees, H., Marinoni, O., Garcia, J.N., Horan, H., 2013. Reprint of Quantifying yield gaps in rainfed cropping systems: a case study of wheat in Australia. Field Crops Res. 143 65-75.

Kanouni, H., Shahab, M.R., Imtiaz, M., Khalili, M., 2012. Genetic variation in drought tolerance in chickpea (Cicer arietinum L.) genotypes. Crop Breed. J. 2, 133-138.

Kassie, B.T., Van Ittersum, M.K., Hengsdijk, H., Asseng, S., Wolf, J., Rötter, R.P., 2014. Climate- induced yield variability and yield gaps of maize (Zea mays L.) in the Central Rift Valley of Ethiopia. Field Crops Res. 160, 41-53.

Lobell, D.B., Cassman, K.G., Field, C.B., 2009. Crop yield gaps: their importance, magnitudes, and causes. Annu. Rev. Environ. Resour. 34, 179-204.

Lu, C., Fan, L., 2013. Winter wheat yield potentials and yield gaps in the North China Plain. Field Crops Res. 143, 98-105.

Meng, Q., Hou, P., Wu, L., Chen, X., Cui, Z., Zhang, F., 2013. Understanding production potentials and yield gaps in intensive maize production in China. Field Crops Res. 143, 91-97.

Monzon, J.P., Merlos, F.A., Mercau, J., Grassini, P., Andrade, F., Taboada, M.A., Hall, A., Cassman, K.G., Jobbágy, E., 2013. Magnitude and variability of maize, wheat, and soybean yield gaps in Argentina. Tampa, 5th November In: Proceedings of the ASA-CSA-SSA International meeting, 2013, p. FL.

Mueller, N.D., Gerber, J.S., Johnston, M., Ray, D.K., Ramankutty, N., Foley, J.A., 2012. Closing yield gaps through nutrient and water management. Nature 490, 254-257.
Nassiri, M., Koocheki, A., 2009. Agroecological zoning of wheat in Khorasan provinces: Estimating yield potential and yield gap. Iran. J. Field Crops Res. 7, 695-709 (In persian with English abstract).

O’Neill, B.C., Dalton, M., Fuchs, R., Jiang, L., Pachauri, S., Zigova, K., 2010. Global demographic trends and future carbon emissions. Proc. Natl. Acad. Sci. U. S. A. 107 (41), 17521-17526.

Rassam, G., Soltani, A., 2007. Optimizing chickpea production management under rainfed conditions using the Computer simulation. In: Proceeding of 2nd National Symposium of Organic Farming, Oct 17-18. University of agriculture Sciences and Natural Resourcess, Gorgan. Iran (In persian with English abstract).

Ray, D.K., Mueller, N.D., West, P.C., Foley, J.A., 2013. Yield trends are insufficient to double global crop production by 2050. PLoS One 8, e66428.

Ritchie, J.T., Gerakis, A., Suleiman, A., 1999. Simple model to estimate field-measured soil water limits. Trans. ASAE 42, 1609-1614.

Sabaghpour, S.H., Mahmodi, A.A., Saeed, A., Kamel, M., Malhotra, R., 2006. Study on chickpea drought tolerance lines under dryland condition of Iran. Indian J. Crop Sci. 1, 70-73.

Sadri, B., Banai, T., 1996. Chickpea in Iran. In: Saxena, N.P., Saxena, M.C., Johansen, C., Virmani, S.M., Harris, H. (Eds.), Adaptation of Chickpea in the West Asia and North Africa Region. ICARDA, Aleppo, Syria, pp. 23-34.

Schulthess, U., Timsina, J., Herrera, J.M., McDonald, A., 2013. Mapping field-scale yield gaps for maize: an example from Bangladesh. Field Crops Res. 143, $151-156$.

Silim, S.N., Saxena, M.C., 1993. Adaptation of spring-sown chickpea to the Mediterranean basin. II. Factors influencing yield under drought. Field Crops Res. 34, 137-146

Sinclair, T.R., Rufty, 2012. Nitrogen and water resources commonly limit crop yield increases, not necessarily plant genetics. Glob. Food Secur. 1, 94-98.

Singh, P., Nedumaran, S., Boote, K.J., Gaur, P.M., Srinivas, K., Bantilan, M.C.S., 2014. Climate change impacts and potential benefits of drought and heat tolerance in chickpea in South Asia and East Africa. Eur. J. Agron. 52, 123-137, Part B.

Smith, P., 2013. Delivering food security without increasing pressure on land. Glob. Food Secur. 2, 18-23.

Soltani, A., Hoogenboom, G., 2003a. Minimum data requirements for parameter estimation of stochastic weather generators. Clim. Res. 25, 109-119.

Soltani, A., Hoogenboom, G., 2003b. A statistical comparison of the stochastic weather generators WGEN and SIMMETEO. Clim. Res. 24, 215-230.

Soltani, A., Sinclair, T.R., 2011. A simple model for chickpea development, growth and yield. Field Crops Res. 124, 252-260.

Soltani, A., Sinclair, T.R., 2012a. Modeling Physiology of Crop Development, Growth and Yield. CAB International, Wallingford, UK, 336p.

Soltani, A., Sinclair, T.R., 2012b. Optimizing chickpea phenology to available water under current and future climates. Eur. J. Agron. 38, 22-31.

Soltani, A., Torabi, B., Zarei, H., 2005. Modeling crop yield using a modified harvest index-based approach: application in chickpea. Field Crops Res. 91, 273-285.

Soltani, A., Maleki, M.H.M., Zeinali, E., 2014. Optimal crop management can reduce energy use and greenhouse gases emissions in rainfed canola production. Int. J. Plant Prod. 8, 587-604

Soltani, A., Khooie, F.R., Ghassemi-Golezani, K., Moghaddam, M., 2001. A simulation study of chickpea crop response to limited irrigation in a semiarid environment. Agric. Water Manag. 49, 225-237.

Soltani, A., Rajabi, M.H., Zeinali, E., Soltani, E., 2013. Energy inputs and greenhouse gases emissions in wheat production in Gorgan. Iran. Energy 50, 54-61.

Soltani, A., Hammer, G.L., Torabi, B., Robertson, M.J., Zeinali, E., 2006. Modeling chickpea growth and development: phenological development. Field Crops Res. 99, 1-13.

Tanaka, A., Saito, K., Azoma, K., Kobayashi, K., 2013. Factors affecting variation in farm yields of irrigated lowland rice in southern-central Benin. Eur. J. Agron. 44, 46-53.

Tilman, D., Balzer, C., Hill, J., Befort, B.L., 2011. Global food demand and the sustainable intensification of agriculture. Proc. Natl. Acad. Sci. U. S. A. 108, 20260-20264.

Vadez, V., Soltani, A., Sinclair, T.R., 2012. Modelling possible benefits of root related traits to enhance terminal drought adaptation of chickpea. Field Crops Res. $137,108-115$.

Vadez, V., Soltani, A., Sinclair, T.R., 2013. Crop simulation analysis of phenological adaptation of chickpea to different latitudes of India. Field Crops Res. 146, 1-9.

van Ittersum, M.K., Cassman, K.G., Grassini, P., Wolf, J., Tittonell, P., Hochman, Z., 2013. Yield gap analysis with local to global relevance-a review. Field Crops Res 143, 4-17.

van Wart, J., van Bussel, L.G.J., Wolf, J., Licker, R., Grassini, P., Nelson, A., Boogaard, H., Gerber, J., Mueller, N.D., Claessens, L., van Ittersum, M.K., Cassman, K.G., 2013. Use of agro-climatic zones to upscale simulated crop yield potential. Field Crops Res. 143, 44-55.

Wang, N., Jassogne, L., vanAsten, P.J.A., Mukasa, D., Wanyama, I., Kagezi, G., Giller K.E., 2015. Evaluating coffee yield gapsandimportantbiotic,abiotic,and management factorslimitingcoffeeproductioninUganda. Eur. J. Agron. 63, 1-11. 